\title{
Vaccination with long NY-ESO-1 79-108 peptide and CpG-B leads to robust activation of CD4 and CD8 $T$ cell responses in stage III/IV melanoma patients, and a new HLA-DR7 epitope
}

\author{
Petra Baumgartner ${ }^{1}$, Carla Costa Nunes ${ }^{2}$, Amélie Cachot $^{2}$, Hélène Maby-El Hajjami ${ }^{3}$, Laurène Cagnon ${ }^{4}$, \\ Marion Braun ${ }^{5}$, Laurent Derré ${ }^{6}$, Jean-Paul Rivals ${ }^{7}$, Donata Rimoldi², Emanuela Romano ${ }^{4}$, Olivier Michielin ${ }^{8}$, \\ Pedro Romero ${ }^{3}$, Camilla Jandus ${ }^{2^{*}}$, Daniel E Speiser ${ }^{3}$
}

From 30th Annual Meeting and Associated Programs of the Society for Immunotherapy of Cancer (SITC 2015) National Harbor, MD, USA. 4-8 November 2015

\begin{abstract}
Although promising, the combination of long synthetic peptides and CpG-B oligodeoxynucleotides has not yet been tested as cancer vaccine. In this Phase I trial, 19 patients received a mean of 8 (range 1-12) monthly vaccines s.c. composed of the long synthetic NY-ESO79108 peptide and CpG-B (PF-3512676), emulsified in Montanide ISA-51. In 18/18 evaluable patients, vaccination induced responses of both CD8 and CD4 T cells, starting early after initiation of immunotherapy and lasting for many months. The $\mathrm{T}$ cells responded antigenspecifically, with strong secretion of IFN $\gamma$ and TNF $\alpha$, irrespective of patient's HLAs. The most immunogenic region of the vaccine peptide was the NY-ESO-183-97 sequence, inducing HLA-DR or -DP restricted CD4 T cell responses in all patients tested. We discovered a novel and highly immunogenic epitope (HLA-DR7/NYESO-187-99); 5/5 HLA-DR7+ patients generated strong CD4 $\mathrm{T}$ cell responses, as detected directly ex-vivo with fluorescent multimers. Thus, vaccination with the long synthetic NY-ESO-179-108 peptide combined with the strong immune adjuvant CpG-B, a TLR-9 agonist, induced integrated, robust and functional CD8 and CD4 $\mathrm{T}$ cell responses in melanoma patients, supporting the further development of this immunotherapeutic approach.
\end{abstract}

\section{Authors' details}

${ }^{1}$ Ludwig Center for Cancer Research at the University of Lausanne and Department of Oncology, University Hospital of Lausanne, Lausanne, Switzerland. 'Ludwig Cancer Research Center, University of Lausanne, Lausanne, Switzerland. ${ }^{3}$ Department of Oncology, Ludwig Cancer Research Center, University of Lausanne, Lausanne, Switzerland. ${ }^{4}$ Department of Oncology, University Hospital Center (CHUV), Lausanne, Switzerland. ${ }^{5}$ Miltenyi Biotech GmbH, Bergisch Galdbach, Germany. ${ }^{6}$ Urology Research Unit, Urology Department, University Hospital Center (CHUV), Lausanne, Switzerland. 7 Department of Otolaryngology, Head and Neck Surgery, University Hospital Center (CHUV), Lausanne, Switzerland. ${ }^{8}$ Centre Hospitalier Universitaire Vaudois, Lausanne, Switzerland.

Published: 4 November 2015

\section{doi:10.1186/2051-1426-3-S2-P437}

Cite this article as: Baumgartner et al:: Vaccination with long NY-ESO-1 79-108 peptide and CpG-B leads to robust activation of CD4 and CD8 T cell responses in stage III/IV melanoma patients, and a new HLA-DR7 epitope. Journal for ImmunoTherapy of Cancer 2015 3(Suppl 2):P437.

Submit your next manuscript to BioMed Central and take full advantage of:

- Convenient online submission

- Thorough peer review

- No space constraints or color figure charges

- Immediate publication on acceptance

- Inclusion in PubMed, CAS, Scopus and Google Scholar

- Research which is freely available for redistribution 